Available online at GSC Online Press Directory

GSC Biological and Pharmaceutical Sciences

e-ISSN: 2581-3250, CODEN (USA): GBPSC2

Journal homepage: https://www.gsconlinepress.com/journals/gscbps

(RESEARCH ARTICLE)

\title{
Effect of different doses of nitrogen on nitrogen fixation and yield of lentil using tracer technique
}

\author{
Kabir Md. Humayun ${ }^{1}$, Das Pronabananda ${ }^{1}$, Islam Md. Monirul 1, ${ }^{*}$, Hossain Md. Belal ${ }^{2}$, Islam Md. Monirul ${ }^{1}$, \\ Mamun A. N. K. ${ }^{1}$ and V. Rallos Roland ${ }^{3}$ \\ ${ }^{1}$ Plant Biotechnology and Genetic Engineering Division, Institute of Food and Radiation Biology, Atomic Energy Research \\ Establishment, G.P.O. Box No-3787, Dhaka-1000, Bangladesh. \\ ${ }^{2}$ Soil Science Division, Bangladesh Institute of Nuclear Agriculture, Mymensingh, Bangladesh. \\ ${ }^{3}$ Agriculture Research Section, Philippine Nuclear Research Institute, Commonwealth Ave., Diliman, Quezon City 1101, \\ Phillipine.
}

Publication history: Received on 20 February 2019; revised on 11 March 2019; accepted on 15 March 2019

Article DOI: https://doi.org/10.30574/gscbps.2019.6.3.0027

\begin{abstract}
Legumes play a predominant role in nitrogen cycling having the unique features of biological nitrogen fixation. An experiment was conducted to estimate yield, nitrogen use efficiency (NUE) and the proportion of nitrogen fixation in plant segments i.e. roots, shoots, leafs and seeds of lentil. Three treatments such as $0 \mathrm{~kg} / \mathrm{ha}, 11.5 \mathrm{~kg} / \mathrm{ha}$ and $25.3 \mathrm{~kg} / \mathrm{ha}$ were used in this experiment. The highest dry matter yield obtained were $43.44 \mathrm{~kg} / \mathrm{ha}, 2677 \mathrm{~kg} / \mathrm{ha}, 1450 \mathrm{~kg} / \mathrm{ha}$ and $1604 \mathrm{~kg} / \mathrm{ha}$ at roots, shoots, leaves and seeds respectively with the treatment $11.5 \mathrm{~kg} / \mathrm{ha} \mathrm{N}$ level. ${ }^{15} \mathrm{~N}$ labelled urea was applied to wheat and lentil at $5 \%{ }^{15} \mathrm{~N}$ atom excess. The total nitrogen content in lentil was found $8.39 \%$ with an average yield of $104.5 \mathrm{~kg} \mathrm{~N} /$ ha whereas it was $1.95 \%$ with an average yield of $102.8 \mathrm{~kg} \mathrm{~N} /$ ha in case of wheat. Nitrogen derived from fertilizer in lentil was $1.173 \%$ with an average fertilizer $\mathrm{N}$ yield of $12.085 \mathrm{~kg} / \mathrm{ha}$ whereas it was $7.538 \%$ with an average yields of $223.16 \mathrm{~kg} \mathrm{~N} / \mathrm{ha}$ in wheat. Lentil fixed around 85\% of its required nitrogen from atmosphere through biological fixation and a minimal amount of $14.387 \%$ of nitrogen was drawn from soil source. Nitrogen use efficiency in seed was $110.1 \%$ in lentil and $36.22 \%$ in wheat which were much higher than the other plant segments in both cases.
\end{abstract}

Keywords: Lentil; ${ }^{15} \mathrm{~N}$ isotope; $5 \%$ Atom excess; NUE; Labeled urea

\section{Introduction}

Lentil (Lens culinaris Medik.) is one of the most important popular pulse crops in Bangladesh. Different varieties of pulses are grown throughout the country. Among the pulse crop, lentil constitutes the main source of protein and it is called poor man meat. It belongs to the leguminosae family and it is locally known as masur. It is thought to have originated in the Near East and then spread to Egypt, central and southern Europe, the Mediterranean basin, Ethiopia, Afghanistan, India and Pakistan, China and later to Latin America [1-2]. Lentil seeds contain 1-2\% fat, 24-32\% protein and minerals (iron, cobalt and iodine) and vitamin (lysine and arginine) [3-4]. These important nutritive values help to overcome malnutrition in our population. Due to the deficiency of these nutrition values, it can be hazardous for the health of the population living in the under developing countries in the world. The important feature of this legume crop is that it can fix atmospheric nitrogen by common soil bacteria (Rhizobium sp). These bacteria are a natural inhabitant in the nodules of this legume. Besides, its cultivation enriches soil nutrient status by adding nitrogen, carbon and organic matter which promotes sustainable crop production system [5]. Rhizobial inoculation alone is not enough for obtaining high yields of legumes because of poor nodulation and nitrogenase activity [6]. Global production of lentil was 6.3 million ton in the year 2016 [7]. In Bangladesh it is cultivated in about 154,449.49 hectares of land and total production

\footnotetext{
* Corresponding author

E-mail address: monirul.rubd@gmail.com
} 
of about 158228 tons of grain with an average yield of $1,073.5 \mathrm{~kg} / \mathrm{ha}$. It contributes about $38.4 \%$ of the total pulse production in the country [8]. Bangladesh is on $8^{\text {th }}$ position in world ranking of lentil production which covers only $2.5 \%$ share of the total lentil produce of the world. The yield potential of lentil in Bangladesh is lower than that of the other lentil growing countries of the world like Canada, India, China etc. [9]. Low organic matter content of soil and nonjudicious application of fertilizers are the main constrain for the low yield potential of lentil and other crop plants.

Nitrogen is the most essential nutrient that frequently limits the crop production. The availabilities and source of nitrogen fertilizer also affect crop yield and soil health. Having effective biological nitrogen fixations, legumes can therefore be grown without nitrogen fertilizer as atmosphere had had more than $70 \%$ nitrogen. Thus to understand the actual benefits of this plant-microbial interaction, it is essential to determine the amount of atmospheric nitrogen fixed by lentil and the nitrogen use efficiency under field condition for better crop management. A suitable method is therefore an important requirement in any study aimed at maximizing biological nitrogen fixation. A little information is available about the quantity of fixed nitrogen in lentil as influenced by a native rhizobial population. Therefore, the present study was undertaken to estimate the amount of atmospheric nitrogen fixed by lentil and nitrogen use efficiency of plants to improve the production and to develop the existing farmer's practice of $\mathrm{N}$ application in agricultural field.

\section{Material and methods}

Field experiment was carried out at regional sub-station of Bangladesh Institute of Nuclear Agriculture (BINA), Ishwardi, Pabna during the period of November-March 2017 to 2018. The experimental design followed randomized complete block design (RCBD) with four replications. The experimental plot size was $4.0 \mathrm{~m} \times 3.0 \mathrm{~m}$. The experimental field was prepared by ploughing, harrowing and hand spade. Weeds, stubbles and crop residues were removed. The physiochemical prosperities of soil in the experimental field were: $\mathrm{pH}=7.4$, clay loam of soil texture, soil organic matter content of $1.61 \%$ on test, total nitrogen $0.069 \%$, available phosphorus $12.18 \mathrm{cmol} / \mathrm{kg}$, available potassium 0.140 $\mathrm{cmol} / \mathrm{kg}$, available sulphur $17.17 \mathrm{cmol} / \mathrm{kg}$, cation exchange capacity (CEC) $30.2 \mathrm{cmol} / \mathrm{kg}$. The recommended fertilizer doses of TSP were applied @160 kg/ha and MOP@110 kg/ha at the time of final land preparation.

In this study, BINA mosur-5 was selected to find out the effect of different nitrogen levels on the yield of lentil and also to estimate the amount of atmospheric nitrogen fixed using ${ }^{15} \mathrm{~N}$. BARI wheat-30 was used as a reference crop. Seeds of lentil were sown on 24 November, 2017 and maintained a row distance $30 \mathrm{~cm}$ with a seed rate of $12 \mathrm{~kg} / \mathrm{ha}$. Intercultural operations were done as and when necessary. Three different concentrations of non-labeled (14N) nitrogen were applied at the rate of $0 \mathrm{~kg} / \mathrm{ha}$ (T0), $11.5 \mathrm{~kg} / \mathrm{ha}$ (T1) and $25.3 \mathrm{~kg} / \mathrm{ha}$ (T2) at the seedling stage of 15 days old seedlings in all the plots except the microplots. In the microplots, the labeled $\left({ }^{15} \mathrm{~N}\right)$ nitrogen with 5.18 atom\% excess was applied at the same dose rate $\left(\mathrm{T}_{2}\right)$ but in the form of aqueous solutions. The control plot was kept free of nitrogen fertilizer. Light irrigation was applied two times within the growing period. First irrigation was applied at 42 days after planting and second was applied at pod filling stage of lentil. Weed control was done two times. Five hills from each plot were randomly selected for data collection i.e. plant height $(\mathrm{cm})$, primary branch/plant, number of nodules/plant, fresh weight of nodules/plant and dry weight of nodules/plant at 50\% flowering stage of the studied plant. Ten hills were randomly selected and uprooted from each plot for collecting data on yield and yield contributing characters such as on plant height (cm), number of primary branch/plant, filling pod/plant (no.), non-filling pod/plant (no.), and 1000 seeds weight (g). Data on seed yield ( $\mathrm{t} / \mathrm{ha}$ ), straw yield ( $\mathrm{t} / \mathrm{ha}$ ) and harvest index was taken from the microplots at the time of harvest. The collected data were analyzed statistically and means were adjudged by Duncan's Multiple Range Test (DMRT). For the estimation of ${ }^{15} \mathrm{~N}$ by using IRMS, the plant samples were collected in four distinct parts i.e. root, shoot, leaf and seed. These samples were then oven dried and grinded into fine powder form. After preparation of sample, data were analyzed using descriptive statistical method. Estimation of percent nitrogen derived from atmosphere (\%Ndfa) can be made by the following equation:

$$
\% \mathrm{Ndfa}=\left(1-\frac{\% \mathrm{Ndff} F}{\% \mathrm{NdffNF}}\right) \times 100
$$

Where $\% \mathrm{NdffF}$ and $\% \mathrm{NdffNF}$ are percentage $\mathrm{N}$ derived from fertilizer by fixing and non-fixing plants, respectively.

The above equation is derived from the following [10-11].

$$
\% \mathrm{Ndff}_{\mathrm{NF}}+\% \mathrm{Ndfs}_{\mathrm{NF}}=100
$$

$\% \mathrm{Ndff}_{\mathrm{F}}+\% \mathrm{NdfS}_{\mathrm{F}}+\% \mathrm{Ndfa}=100$ 
Kabir et al. / GSC Biological and Pharmaceutical Sciences 2019, 06(03), 069-075

$$
\frac{\% \mathrm{NdffNF}}{\% \mathrm{NdfsNF}}=\frac{\% \mathrm{NdffF}}{\% \mathrm{NdfsF}}
$$

Where $\% \mathrm{Ndfs}_{\mathrm{F}}$ and $\% \mathrm{Ndfs}_{\mathrm{NF}}$ are the percentage of $\mathrm{N}$ derived from soil in the fixing and non-fixing crops, respectively.

$$
\% \text { Ndff (Weighed average })=\frac{\text { Total } \mathrm{N} \text { ferti.yeild }}{\text { Total } \mathrm{N} \text { yield }} \times 100
$$

Nitrogen use efficiency of different plant segments was calculated using the following equation:

$$
\operatorname{NUE}(\%)=\frac{\operatorname{Ndff}\left(\frac{\mathrm{g}}{\mathrm{m} 2}\right)}{\operatorname{Applied~}\left(\frac{\mathrm{g}}{\mathrm{m} 2}\right)} \times 100
$$

\section{Results}

Legume has the almost idiosyncratic attribute to quantify the contribution of biological nitrogen fixation (BNF) using the ${ }^{15} \mathrm{~N}$ natural abundance technique that can be used without interference to the plant environment [12]. Nodule formation in roots plays the major part of this mechanism which can fix atmospheric nitrogen using rhizobium bacteria. Cultivation of lentil require lower amount of nitrogen fertilizer compared with other crops due to its own mechanism of BNF. Therefore, isotopic technique is necessary for better crop management and optimizing the art of cultivation. In this part, the yield and yield contributing traits of lentil are analyzed depending on the different fertilizer doses. The total nitrogen yield of the different plant segments and the amount of nitrogen derived from fertilizer were also estimated. Using isotopic techniques, it is also possible to determine nitrogen use efficiency. Finally, the atmospheric nitrogen fixed by the plant was also estimated.

\subsection{Yield}

Table-1 showed that the maximum (43.44 kg/ha) root yield was found with the treatment T1 (11.5 kg/ha N-level) and lowest value $(37.65 \mathrm{~kg} / \mathrm{ha})$ was obtained at T0 $(0 \mathrm{~kg} / \mathrm{ha} \mathrm{N}$-level). In case of shoot yield the highest value $(2677 \mathrm{~kg} / \mathrm{ha})$ was obtained at T1 and lowest $(1720 \mathrm{~kg} / \mathrm{ha})$ was found at T2 $(25.3 \mathrm{~kg} \mathrm{~N} / \mathrm{ha})$. In the amount of leaves, the maximum (1450 kg/ha) was found with T1 and lowest value $(1080 \mathrm{~kg} / \mathrm{ha})$ was obtained at T0. The highest (1604 kg/ha) seed yield was recorded with T1 and the lowest value $(1196 \mathrm{~kg} / \mathrm{ha})$ was obtained at T0. These data indicated that each parameter increased with the enhancement of nitrogen fertilizer at a certain level but decreased with the further increase of nitrogen. This might be due to the over doses of application of nitrogen fertilizer made toxic for the plant and also inhibited nodule formation.

Table 1 Mean comparison of yield and yield components of lentil under different $\mathrm{N}$-levels

\begin{tabular}{lllll}
\hline Treatments & Root yield (kg/ha) & Shoot yield (kg/ha) & Leaf yield (kg/ha) & Seed yield (kg/ha) \\
\hline To & 37.65 & 1903 & 1190 & 1430 \\
T1 & 43.44 & 2677 & 1450 & 1604 \\
T2 & 1720 & 1080 & 1196 \\
Mean & 38.01 & $2100 \mathrm{a}$ & $1240 \mathrm{a}$ & $1410 \mathrm{a}$ \\
\hline
\end{tabular}

This investigation is slightly different to Rabbi [13] and some other reports [14-17] who suggested that seed yield significantly increase with the increasing levels of nitrogen fertilizer. This difference may be due to the effect of genotypes of the plant studied, environmental conditions and the effect of nitrogenase enzyme. Sarker and Sing [18] reported about the significant effects of genotypes on the seed and straw yields of lentil. Significant genotype verses environment interaction was also observed for yield among a wide range of chickpea genotypes [19]. [20] Reported on the effect of locations and growing years on seed yield of field pea and lentil. Therefore, it is prerequisite to choose the appropriate pulse crops to maximize the production in a specific growth condition. All plant segments i.e. roots, shoots, leaves and seeds studied, it was observed that highest value was with the treatment of T1. Among the different plant segments studied, seed weight contained $27.78 \%$ of total dry matter compared with shoot (average of $46.36 \%$ ) and leaf $(25.11 \%)$. On the other hand, root showed the lowest value $(0.75 \%)$ of total dry matter content. Therefore, it was found that seed yield was mostly relied on the yield of shoot. This result is somewhat different from the study of [21] and [22] where it was shown that seed yield was dependent on leaf weight. These might be due to the effect of genotypes. 


\subsection{Nitrogen uptake}

In this study with lentil, it was found that the percent of total nitrogen uptake by root, shoot, leaf and seed were 1.295, $1.022,1.778$ and 4.295 respectively. In the amount of total $\mathrm{N}$ yield were $0.514 \mathrm{~kg} / \mathrm{ha}, 21.46 \mathrm{~kg} / \mathrm{ha}, 22.04 \mathrm{~kg} / \mathrm{ha}$ and $66.56 \mathrm{~kg} / \mathrm{ha}$ in the different plant segments of root, shoot, leaves and seeds accordingly. Among these plant segments, seeds showed the highest nitrogen uptake compare to other plant segments in both cases. This data also indicated that nitrogen was accumulated in seed more than ( 2 to 4 times) higher than other plant segments which is in accordance with the result of [23]. This table also showed that percentage of nitrogen derived from fertilizer (\%Ndff) of root, shoot, leaf and seed were $0.468,0.336,0.219$, and 0.150 respectively. Likewise the fertilizer $\mathrm{N}$ yield were $0.186 \mathrm{~kg} / \mathrm{ha}, 7.061$ $\mathrm{kg} / \mathrm{ha}, 2.719 \mathrm{~kg} / \mathrm{ha}$ and $2.119 \mathrm{~kg} / \mathrm{ha}$ respectively. Results showed that the highest value of $\% \mathrm{Ndff}$ was found in root. In wheat, table 3 showed the concentration of nitrogen in different plant segments i.e. root, shoot, leaf and seed were $0.411 \%, 0.373 \%, 0.936 \%$ and $1.950 \%$ whereas the total nitrogen yield were $2.92 \mathrm{~kg} / \mathrm{ha}, 19.37 \mathrm{~kg} / \mathrm{ha}, 17.49 \mathrm{~kg} / \mathrm{ha}$ and $62.99 \mathrm{~kg} / \mathrm{ha}$ respectively. These data indicated that the nitrogen concentration of shoot is less than that of other plant segments as can be expected due to the accumulation of nutrient for seed formation from shoots. This study showed that seed accumulated highest nitrogen uptake compare to other plant segments studied in both the cases. This table also showed that $\% \mathrm{Ndff}$ of root, shoot, leaf and seed were $1.592 \%, 1.973 \%, 2.127 \%$ and $2.151 \%$, respectively. On the other hand, the fertilizer nitrogen yield of root, shoot, leaf and seed were showed $11.30 \mathrm{~kg} / \mathrm{ha}, 102.6 \mathrm{~kg} / \mathrm{ha}, 39.78 \mathrm{~kg} / \mathrm{ha}$ and $69.48 \mathrm{~kg} / \mathrm{ha}$ respectively. In this study, it was found that the highest value of Ndff showed in seed. Ndff is less than total $\mathrm{N}$ content in both cases of percentage and amount of fertilizer nitrogen yield for all plant segments studied.

Comparing the fixing crop lentil with the reference crop wheat, a significant difference was found in case of total nitrogen content and nitrogen derived from fertilizer. The reference plant wheat accumulated more nitrogen in the soil applied with ${ }^{15} \mathrm{~N}$-labelled Urea (Table 3 ), but the total $\mathrm{N}$ accumulated was far less $(<5 \%)$ than that accumulated by fixing lentil plants (Table 2). It was obviously from the study that lentil fixed small proportion (up to 1.173\%) from the applied labelled fertilizer of its nitrogen. In contrast, wheat derived up to $7.538 \%$ of its nitrogen from the labelled fertilizer. The fact that the fixing lentil plants had much lower ${ }^{15} \mathrm{~N}$ enrichment than the reference crop reveals that the lentil plants obtained very high proportions of their $\mathrm{N}$ from biological nitrogen fixation (BNF). From these data, it can be inferred that wheat meets up its nitrogen demand mainly from fertilizer and soil than lentil as wheat lacks the nitrogen fixing nodule.

Table 2 Nitrogen yield and fertilizer $\mathrm{N}$ yield parameters of different plant segments of lentil

\begin{tabular}{cccccccccccccc}
\hline \multirow{2}{*}{$\begin{array}{c}\text { Plant } \\
\text { segments }\end{array}$} & \multicolumn{3}{c}{ N contents (\%) } & \multicolumn{3}{c}{ N yield (Kg/ha) } & \multicolumn{3}{c}{ Ndff (\%) } & \multicolumn{3}{c}{ Fertile N yield (kg/ha) } \\
\cline { 2 - 13 } & Max. & Min. & Mean & Max. & Min. & Mean & Max. & Min. & Mean & Max. & Min. & Mean \\
\hline Root & 1.511 & 0.976 & 1.295 & 0.600 & 0.387 & 0.514 & 0.578 & 0.360 & 0.468 & 0.23 & 0.143 & 0.186 \\
Shoot & 1.139 & 0.897 & 1.022 & 23.92 & 18.84 & 21.46 & 0.349 & 0.302 & 0.336 & 7.33 & 6.342 & 7.061 \\
Leaf & 2.085 & 1.469 & 1.778 & 25.85 & 18.22 & 22.04 & 0.274 & 0.187 & 0.219 & 3.40 & 2.319 & 2.719 \\
Seed & 4.688 & 4.031 & 4.295 & 66.10 & 56.84 & 60.56 & 0.171 & 0.126 & 0.150 & 2.41 & 1.777 & 2.119 \\
Total & & & 8.390 & & & 104.5 & & & 1.173 & & & 12.085 \\
\hline
\end{tabular}

Table 3 Nitrogen yield and fertilizer $\mathrm{N}$ yield parameters of different plant segments of wheat under field condition

\begin{tabular}{lllllllllllll}
\hline Plant & \multicolumn{3}{c}{ N contents (\%) } & \multicolumn{3}{c}{ N yield (Kg/ha) } & \multicolumn{3}{c}{ Ndff (\%) } & \multicolumn{4}{c}{ Fertile N yield (kg/ha) } \\
segments & Max. & Min. & Mean & Max. & Min. & Mean & Max. & Min. & Mean & Max. & Min. & Mean \\
\hline Root & 0.539 & 0.301 & 0.411 & 3.83 & 2.14 & 2.92 & 1.764 & 1.313 & 1.592 & 12.5 & 9.32 & 11.30 \\
Shoot & 0.42 & 0.284 & 0.373 & 21.84 & 14.77 & 19.37 & 2.188 & 1.873 & 1.973 & 113.8 & 97.40 & 102.6 \\
Leaf & 1.187 & 0.726 & 0.936 & 22.20 & 13.58 & 17.49 & 2.404 & 1.968 & 2.127 & 45.0 & 36.80 & 39.78 \\
Seed & 2.144 & 1.705 & 1.950 & 69.25 & 55.07 & 62.99 & 2.266 & 1.993 & 2.151 & 73.2 & 64.37 & 69.48 \\
Total & & & 3.670 & & & 102.8 & & & 7.538 & & & 223.16 \\
\hline
\end{tabular}




\subsection{Nitrogen use efficiency}

In lentil, the maximum (110.1\%) nitrogen use efficiency (NUE) was found in seed followed by other plant segments whereas the maximum (36.22\%) nitrogen use efficiency (NUE) in wheat was also showed in seed followed by other plant segments (figure 1). However, lentil showed the higher proportion of nitrogen use efficiency than that of wheat plant segments in all the cases.

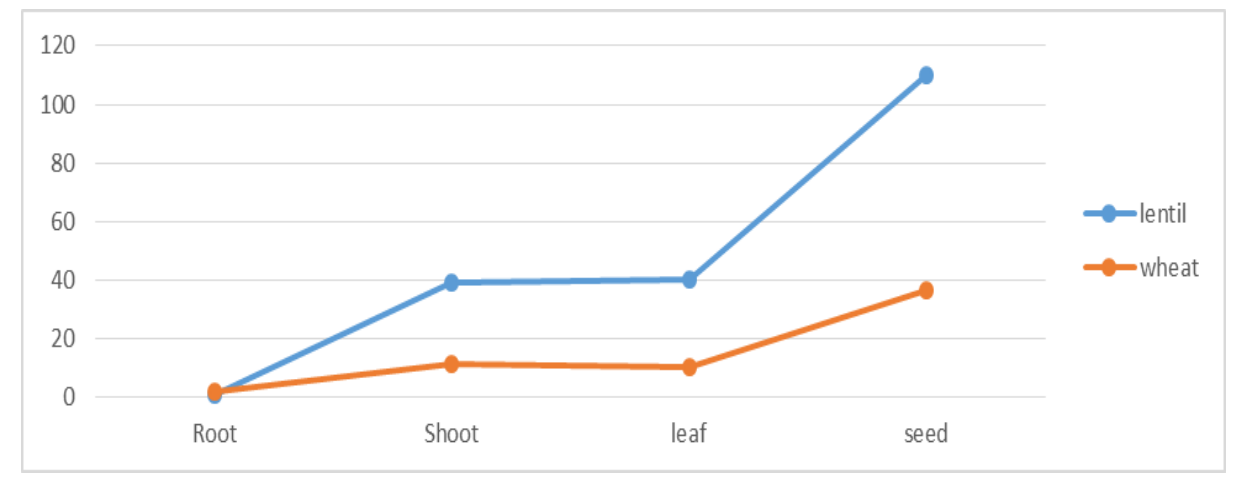

Figure 1 Comparison study of plant segments for nitrogen use efficiency (NUE) of lentil and wheat

\subsection{Nitrogen fixation}

Jensen et al. [24] reported that the amount of $\mathrm{N}$ fixed by the symbiotic relationship between legumes and the soil rhizobial bacteria is estimated by the relative dependence of the crop on biological nitrogen fixation for growth (i.e. $\% \mathrm{Ndfa}$ ) and the amount of $\mathrm{N}$ accumulated by the crop over the growing season. Significant variation in the amount of $\% \mathrm{Ndfa}$ by various pulses species has been reported by different authors in the past. Many authors [25-27] reported that about $58-80 \% \mathrm{~N}$ is derived from the atmosphere under favourable condition. However, in this study, the maximum nitrogen obtained by lentil was up to $85 \%$ from atmospheric nitrogen through BNF which is in accordance with the earlier report [25]. The remaining proportion was up to $14 \%$ amount to $15.03 \mathrm{~kg} \mathrm{~N} /$ ha taken up from the soil. According to other researchers [27-29], symbiotic $\mathrm{N}$ fixation in lentil yields about 69 to $154 \mathrm{~kg} \mathrm{~N} / \mathrm{ha}$ whereas $88.23 \mathrm{~kg} \mathrm{~N} / \mathrm{ha}$ was found in this study. Those trends of \%Ndfa were somewhat similar to our observations, although the amount of $\mathrm{N}$ fixed was relatively low in our study which may be due to the genotypic or environmental effect. Abi-Ghanem [30] also reported the genotypic background effects of biological nitrogen fixation in pulses, such as pea and lentil. Yang [31] found the lowest biological nitrogen fixation rate in Saskatchewan and concluded that it was due to the more dry conditions. Our results also indicated the significant impact of growing environment on \%Ndfa and biological nitrogen fixation by lentil which is in agreement with study mentioned above.

Table 4 An overview of different sources of nitrogen accumulated by lentil under field conditions

\begin{tabular}{|c|c|c|c|c|c|c|}
\hline \multirow{2}{*}{$\begin{array}{l}\text { Plant } \\
\text { segments }\end{array}$} & \multicolumn{3}{|c|}{ Proportion of nitrogen (\%) } & \multicolumn{3}{|c|}{ Amount of nitrogen $(\mathrm{kg} / \mathrm{ha})$} \\
\hline & Ndff & Ndfa & Ndfs & Ndff & Ndfa & Ndfs \\
\hline Root & 0.468 & & & 0.002 & & \\
\hline Shoot & 0.336 & & & 0.072 & & \\
\hline Leaf & 0.219 & & & 0.048 & & \\
\hline Seed & 0.150 & & & 0.091 & & \\
\hline Total & 1.173 & 84.44 & 14.387 & $12.084^{*}$ & 88.23 & 15.03 \\
\hline
\end{tabular}

\section{Conclusion}

This investigation showed the specific results of the amount of atmospheric $\mathrm{N}$ fixed in a particular environment and NUE of the plants in case of lentil. This study will also help to develop sustainable pulse production systems and better crop management. 


\section{Compliance with ethical standards}

\section{Acknowledgments}

Authors are grateful to the FAO/IAEA for providing $15 \mathrm{~N}$ labeled Urea to conduct this research work for the estimation of BNF under the project RAS 5070.

\section{Disclosure of conflict of interest}

We declare that there are no conflict of interest related to this paper.

\section{References}

[1] Cubero JI. (1981). Origin, domestication and evolution. In C. Webb and G. C. Hawtin (Eds.), Lentils. Commonwealth Agricultural Bureau, Slough, UK, 15-38.

[2] Duke JA. (1981). Handbook of legumes of World economic importance. Plenum Press, New York, 52-57.

[3] Kowieska A and Petkov K. (2003). Lentils (Lens culinaris Medic.) estimation based on macro and microelements content. Zywienie Czowieka i Metabolism, 3(3/4), 1012-1014.

[4] Bhatty RS. (1988). Composition and quality of lentil (Lens culinaris Medik.): a review. Canadian Institute of Food Science and Technology journal, 21, 144-160.

[5] Sarker A, Erskine W and Saxena MC. (2004). Global perspective on lentil improvement. In: Masood A, Singh B, Kumar S, Dhar V (eds) Pulses in new perspective. Indian Institute of Pulses Research, Kanpur, India, 543-550.

[6] Sosulski F and Buchan JA. (1978). Effects of Rhizobium and nitrogen fertilizer on nitrogen fixation and growth of field peas. Canadian Journal Plant Science, 58,553-556.

[7] https://www.researchgate.net/publication/40131388_Response_of_two_varieties_of_lentil_to_soil_salinity [accessed Jan 26 2019].

[8] BBS (Bangladesh Bureau of Statistics). (2016). Year book of agricultural statistics of Bangladesh. Statistics Division Ministry of Planning, Government of Bangladesh.

[9] FAOSTAT. http://www.factfish.com/statisticcountry/bangladesh/lentils\%2C\%20production\%20quantity.

[10] Fried M and Middelobe V. (1977). Measurement of the amount of nitrogen fixed by a legume crop. Plant soil, 47, 713-715.

[11] Hardarson G. (1990). Use of Nuclear Techniques in Studies of Soil-Plant Relationships. IAEA, Vienna.

[12] Peoples MB, Faizah AW, Rerkasem B and Herridge DF. (1989). Methods for evaluating nitrogen fixation by nodulated legumes in the field. Canberra: Australian Centre for International Agricultural Research, 75.

[13] Rabbi AKMZ, Paul AK and Sarker JR. (2011). Effects of nitrogen and molybdenum on the growth and yield of garden pea (Pisum sativum L.) International Journal of Bio-resouce and Stress Management, 2(2), 230-235.

[14] Sharma RK. (1999). Chemical fertilizers can increase productivity in legumes Crop research, 18(1), 159-160.

[15] Mandal KG and Majumdar DK. (2001). Agro-physiological characteristics of lentil in relation to irrigation, nitrogen and plant density. Journal of Interacademicia, 5(2), 156-161.

[16] Nakhzeri Moghadam A and Ramroudi M. (2003). Effect of planting date and nitrogen rate on yield and yield components of lentil. Journal of Agriculture and Resource Science, 9(4), 33-41.

[17] Togay Y, Togay N, Dogan y and Ciftici V. (2005). Effects of nitrogen levels forms on the yield and yield components of lentil (Lens culinaris Medic.). Asian Journal of Plant Sciences, 4(1), 64-66.

[18] Sarker A and Singh M. (2015). Improving breeding efficiency through application of appropriate experimental designs and analysis models: a case of lentil (Lens culinaris Medikus subsp. culinaris) yield trials. Field Crops Research 179, 26-34.

[19] Krishnamurthy L, Gaur PM, Basu PS, Chaturvedi SK, Tripathi S, Vadez V, Rathore A, Varshney RK and Gowda CLL. (2011). Large genetic variation for heat tolerance in the reference collection of chickpea (Cicer arietinum L.) germplasm. Plant Genetic Resource: Characterization and Utilization, 9(01), 59 -69. 
[20] Ito D, Afshar RK, Chen C, Miller P, Kephart K, McVay K, Lamb P, Miller J, Bohannon B and Knox M. (2016). Multi environmental evaluation of dry pea and lentil cultivars in Montana using the AMMI model. Crop Science 56, 520529.

[21] Dutta R K and Mondal MMA. (1998). Evaluation of lentil genotypes in relation to growth characteristics, assimilate distribution and yield potential. LENS Newsletter 25, 51-55.

[22] Mondal MMA, Puteh AB, Malek MA, Ismail MR, Rafii MY and Latif MA. (2012). Seed yield of mungbean in relation to growth and developmental aspects. The Scientific World Journal, Article ID 425168, 1-7.

[23] Chien SH, Carmona G, Menon RG and Hellmus DT. (1993). Effect of phosphate rock sources on biological nitrogen fixation by soybean. Fertilizer Research 34,153-159.

[24] Jensen ES, Peoples MB and Hauggaard-Nielsen H. (2010). Faba bean in cropping systems. Field Crops Research $115,203-216$.

[25] Saxena MC and Silim SN. (1990). Food Legume Improvement Program: Annual Report. International Center for Agricultural Research in the Dry Areas (ICARDA), Aleppo, Syria

[26] Badarneh DMD and Ghawi IO. (1994). Effectiveness of inoculation on biological nitrogen fixation and water consumption by lentil under rainfed conditions. Soil Biology and Biochemistry, 26, 1-5.

[27] Kurdali F, Kalifo K and Al Schamma M. (1997). Cultivar differences in nitrogen assimilation, partitioning and mobilization in rain-fed grown lentil. Field Crop Research 54, 235-243

[28] Schulz S, Keatinge JDH, Wells GJ. (1999). Productivity and residual effects of legumes in rice-based cropping systems in a warm-temperate environment. II. Residual effects on rice. Field Crops Research, 61 (1), 37-49

[29] Schmidtke K, Neumann A, Hof C and Rauber R. (2004). Soil and atmospheric nitrogen uptake by lentil (Lens culinaris Medic.) and barley (Hordeum vulgare ssp. nudum L.) as monocrops and intercrops. Field Crops Research, 87, 245-256.

[30] Abi-Ghanem R, Carpenter-Boggs L and Smith JL. (2011). Cultivar effects on nitrogen fixation in peas and lentils. Biology and Fertility of Soils, 47, 115-120.

[31] Yang JY, Drury CF, Yang XM, De Jong R, Huffman EC, Campbell CA and Kirkwood V. (2010). Estimating biological N2 fixation in Canadian agricultural land using legume yields. Agriculture, Ecosystem \& Environment, 137, 192 201.

\section{How to cite this article}

Kabir MH, Das P, Islam MM, Hossain MB, Islam MM, Mamun ANK and V Rallos R. (2019). Effect of different doses of nitrogen on nitrogen fixation and yield of lentil using tracer technique. GSC Biological and Pharmaceutical Sciences, 6(3), 69-75. 